\title{
FPWM TECHNIQUE BASED CONVERTER FOR IM DRIVES
}

\author{
Habib BENBOUHENNI \\ Ecole Nationale Polytechnique d'Oran Maurice Audin, Oran, Algeria \\ Tel.+213663956329, E-mail: habib_benbouhenni@yahoo.com
}

\begin{abstract}
This article presents an improved pulse width modulation (PWM) based on fuzzy logic (FL) of induction motor (IM). The major problem that is usually associated with PWM technique is the high total harmonic distortion (THD), stator flux ripple and electromagnetic torque ripples. To overcome these problems a PWM strategy is proposed based on the fuzzy logic controller (FPWM). The fuzzy proposed controller is shown to be able to reduce the THD of stator current, electromagnetic torque ripple and stator flux ripple. The simulation results are shown by using MATLAB/SIMULINK software.
\end{abstract}

Keywords: Pulse width modulation, induction motor, total harmonic distortion, FPWM, fuzzy logic.

\section{INTRODUCTION}

Fuzzy logic is recently gutting increasing emphasis in drive command applications. Recent years, fuzzy logic control has found many applications in the past two decades. This is so largely increasing because fuzzy logic control has the capability to command nonlinear uncertain systems even in the case where no mathematical model is available for the command system [1].

The induction motor (IM) is of two types. One is a squirrel cage and other is slip ring induction motor. Many works of literature are available on the command of IM and are discussed as follows. However, the IM is suitable electromechanical systems for a large spectrum of industrial applications. This is due to their high reliability, relatively low cost, and modest maintenance requirements [2]. On the other hand, IMs are considered as nonlinear, multivariable and highly coupled systems. However, IMs have been used especially in closed-loop for variable speed applications [3].

Among the various pulse width modulation (PWM) strategies, the sinus pulse width modulation (SPWM) technique is most used one. Typically, there are many types of PWM inverters topologies. Space vector modulation (SVM) method [4, 5]. Selective harmonic elimination strategy (SHEPWM) [6, 7]. Inverted sine carrier pulse width modulation (ISCPWM) method [8]. Third harmonic injection PWM strategy [9, 10]. Discontinuous pulse width modulation (DPWM) technique [11]. These modulation techniques are used in order to reduce the total harmonic distortion (THD).

Traditionally the pulse width modulation strategy is widely used in variable speed drive of IM, especially for scalar command where the stator voltage and frequency can be controlled with a minimum online computational requirement. In addition, this technique is easy to implement. However, this strategy has the following drawbacks. This method is unable to fully utilize the available DC bus supply voltage to the voltage source inverter (VSI). This technique gives more total harmonic distortion [12].

In order to reduce the THD value of stator current and give a more minimum ripple of electromagnetic torque. One way to improve PWM modulation performance is to combine it with fuzzy logic to form a fuzzy pulse width modulation (FPWM). The design of a PWM technique incorporating fuzzy logic command helps in achieving reduced THD value, simple rule base, simple command, and robustness against disturbances and nonlinearities [13].

In this article, two differents PWM inverter will be compared with each other. These two modulations are classical PWM technique and FPWM technique. The proposed modulation techniques are described clearly and simulation results are reported to demonstrate its effectectivness. The proposed modulation techniques are implemented with Matlab/Simulink.

\section{MODEL OF INDUCTION MOTOR}

The traditional electrical equations of the induction motor in the Concordia frame are written as follows:

$$
\begin{aligned}
& \left\{\begin{array}{l}
V_{s \alpha}=R_{s} \cdot I_{s \alpha}+\frac{d \Phi_{s \alpha}}{d t} \\
V_{s \beta}=R_{s} \cdot I_{s \beta}+\frac{d \Phi_{s \beta}}{d t}
\end{array}\right. \\
& \left\{\begin{array}{l}
0=R_{r} \cdot I_{r \alpha}+\frac{d \Phi_{r \alpha}}{d t}+p \Omega_{m} \Phi_{r \beta} \\
0=R_{r} \cdot I_{r \beta}+\frac{d \Phi_{r \beta}}{d t}-p \Omega_{m} \Phi_{r \alpha}
\end{array}\right. \\
& \left\{\begin{array}{l}
\Phi_{s \alpha}=L_{s} \cdot I_{s \alpha}+L_{M} I_{r \beta} \\
\Phi_{s \beta}=L_{s} \cdot I_{s \beta}+L_{M} I_{r \alpha}
\end{array}\right. \\
& \left\{\begin{array}{l}
\Phi_{r \alpha}=L_{r} \cdot I_{r \alpha}+L_{M} I_{s \beta} \\
\Phi_{r \beta}=L_{r} \cdot I_{r \beta}+L_{M} I_{S \alpha}
\end{array}\right.
\end{aligned}
$$

The equation of the dynamic rotor rotation can be expressed as :

$$
\frac{d \Omega_{m}}{d t}=\frac{1}{J}\left[T_{e}-T_{L}-f \Omega_{m}\right]
$$

The electromagnetic torque Te can be expressed by the following formulas : 


$$
\begin{aligned}
& T_{e}=-p \frac{m_{s}}{2} L_{M} I_{m}\left(I_{s}^{*} \cdot I_{r}\right) \\
& T_{e}=p \frac{m_{s}}{2} I_{m}\left(\Phi_{s}^{*} \cdot I_{s}\right)
\end{aligned}
$$

Where :

$\mathrm{T}_{\mathrm{e}}$ : Electromagnetic torque.

$\mathrm{T}_{\mathrm{L}}$ : Load torque.

$\mathrm{f}$ : Viscous constant.

$\Omega_{\mathrm{m}}$ : Angular speed of the motor.

$\Phi_{\mathrm{s} \alpha}, \Phi_{\mathrm{s} \beta}$ : Stator flux vector components in stationary $\alpha-\beta$ coordinate system.

$\Phi_{\mathrm{r} \alpha}, \Phi_{\mathrm{r} \beta}$ : Rotor flux vector components in stationary $\alpha-\beta$ coordinate system.

$\Phi_{\mathrm{s}}$ : Space vector of the stator flux linkage.

$\Phi_{\mathrm{r}}$ : Space vector of the rotor flux linkage.

$\mathrm{R}_{\mathrm{r}}$ : Rotor phase windings resistance.

$\mathrm{R}_{\mathrm{s}}$ : Stator phase windings resistance.

$\mathrm{p}$ : Number of pole pairs.

$\mathrm{ms}$ : Number of phase windings.

$\mathrm{L}_{\mathrm{M}}$ : Main, Magnetizing inductance.

$\mathrm{L}_{\mathrm{s}}$ : Stator winding self-inductance.

$\mathrm{L}_{\mathrm{r}}$ : Rotor winding self-inductance.

$\mathrm{I}_{\mathrm{s} \alpha}, \mathrm{I}_{\mathrm{s} \beta}$ : Stator current vector components in stationary $\alpha-\beta$ coordinate system.

$\mathrm{I}_{\mathrm{r} \alpha}, \mathrm{I}_{\mathrm{r} \beta}$ : Stator current vector components in stationary $\alpha-\beta$ coordinate system.

\section{VOLTAGE SOURCE INVERTER}

The three-phase two-level voltage source inverter (VSI) consists of six active switches. The basic construction of the inverter is shown in Fig. 1. The converter consists of the three legs with IGBT transistors and free-wheeling diodes. The inverter is supplied by a voltage source composed of a diode rectifier with a $\mathrm{C}$ filter in the dc-link. The capacitor $\mathrm{C}$ is typically large enough to obtain adequately low voltage source impedance for the alternating current component in the dc-link [14].

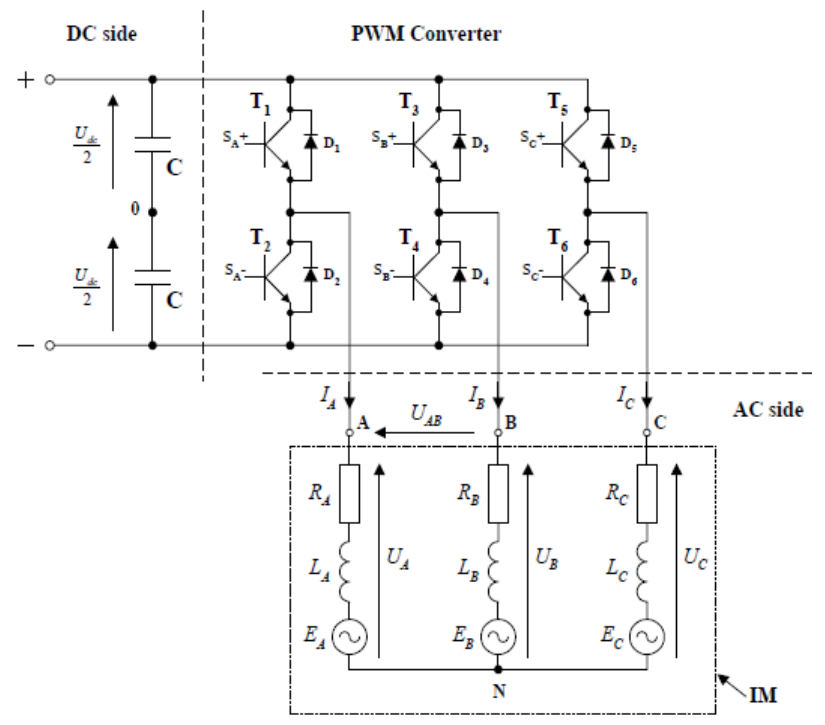

Fig. 1 Structure of the VSI

\section{PULSE WIDTH MODULATION}

Different Pulse-Width Modulation (PWM) command strategies have been proposed in order to give minimum the residual harmonics at the output and to increase the performances of the inverters. The most popular one is probably the Sinusoidal pulse width modulation method (SPWM) which shifts the harmonics to high frequencies by using high-frequency carriers [15]. However, The modulation technique is an important part of the command structure. It should provide features like [14]:

- Wide range of linear operation.

- Low content of higher harmonics in voltage and current.

- Low frequency harmonics.

- Operation in over modulation.

- Reduction of common mode voltage.

- Minimal number of switching to decrease switching losses in the power components.

Fig. 2 shows the principle of the traditional PWM strategy of the two-level inverter for IM drive.

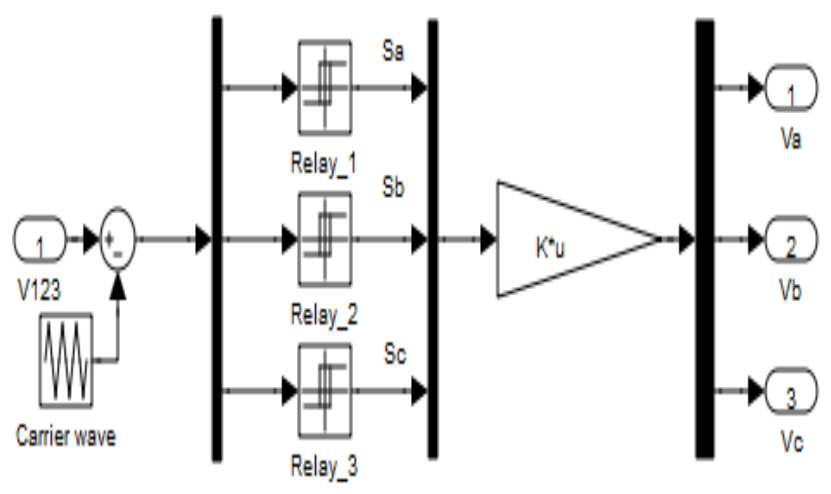

Fig. 2 Block diagram of the PWM inverter.

In PWM strategy three reference signals V1, V2, V3 are compared with triangular carrier signal $V p$, which is common to all three phases. In this way, the logical signals $\mathrm{S}_{\mathrm{A}}, \mathrm{S}_{\mathrm{B}}, \mathrm{S}_{\mathrm{C}}$ are generated.

The modulation index $m$ is defined as:

$$
m=\frac{V_{i}}{V p}
$$

Where :

$V_{i}$ : Peak value of the modulating wave (i=1, 2 or 3 ).

$\mathrm{Vp}$ : Peak value of the carrier wave.

The modulation index $m$ can be varied between 0 and 1 to give a linear relation between the reference and output wave.

The satisfied of the higher harmonics current and electromagnetic interference generated in the inverter fed drive depends on the modulation strategy. Therefore, pulse width modulation techniques are investigated from this point of view. To reduce these disadvantages several methods have been proposed. In this paper, we propose new modulation technique based on a fuzzy logic regulator. 


\section{FUZZY PULSE WIDTH MODULATION}

Fuzzy logic (FL) is identified as the universal approximators and has numerous applications in command design and identification [16]. Zadeh first introduced the fuzzy set theory in 1965 [17]. However, this technique is able to use human reasoning not in terms of discrete symbols and numbers, but in terms of fuzzy sets. These terms are quite flexible with respect to the definition and values [18].

Fuzzy pulse width modulation technique (FPWM) is similar to traditional PWM strategy. However, the hysteresis controllers are replaced by the FL controllers. The construction of the PWM strategy with fuzzy logic technique is represented by Fig. 3. However, the FPWM strategy has numerous advantages, reducing the electromagnetic torque ripple of IM drives, gives more minimum THD value of stator current, simple rule base, simple command and robustness against disturbances.

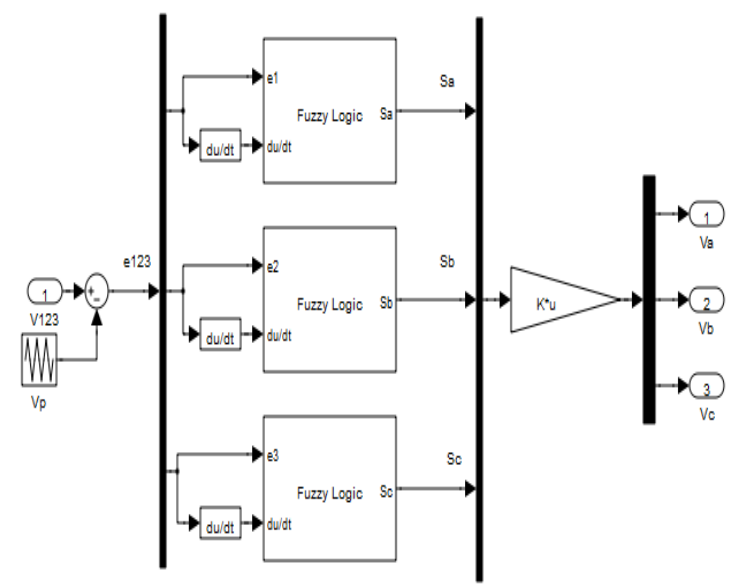

Fig. 3 Block diagram of the FPWM inverter.

With : $\mathrm{K}^{*} \mathrm{u}=(\mathrm{E} / 3)^{*}[2-1-1 ;-1 \quad 2-1 ;-1-1 \quad 2]$.
The FL rules are developed using linguistic changes that are formulated in the form of «IF THEN » rules. The Table 1 shows this rules $[19,20]$.We use the following designations for membership functions:
NB: Negative Big.
NS: Negative Small.
PB: Positive Big.
PM: Positive Middle.
PS: Positive Small.
EZ: Equal Zero.
NM: Negative Middle.

The FL controller contains three blocks: fuzzification, fuzzy rule base and defuzzification. However, the universes of discourses are first partitioned into the 7 linguistic changes NB, NM, NS, EZ, PS, PM, PB. The block diagram of Fuzzy regulator based hysteresis comparators is shown in Fig. 4.

The membership function designation for the input changes and output is given by Fig. 5 .

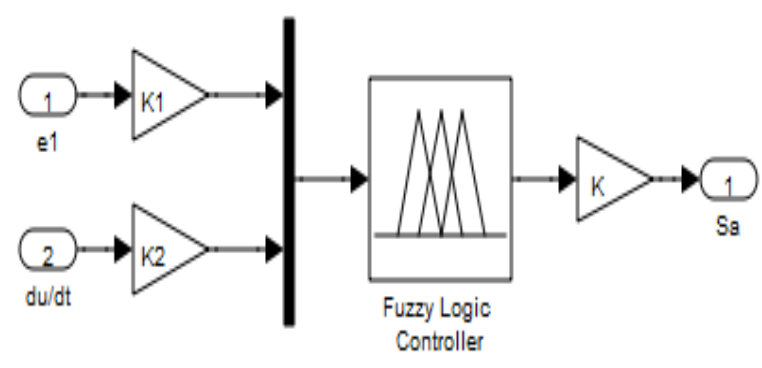

Fig. 4 Block diagram of fuzzy controller.

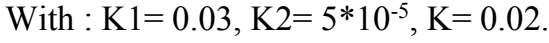
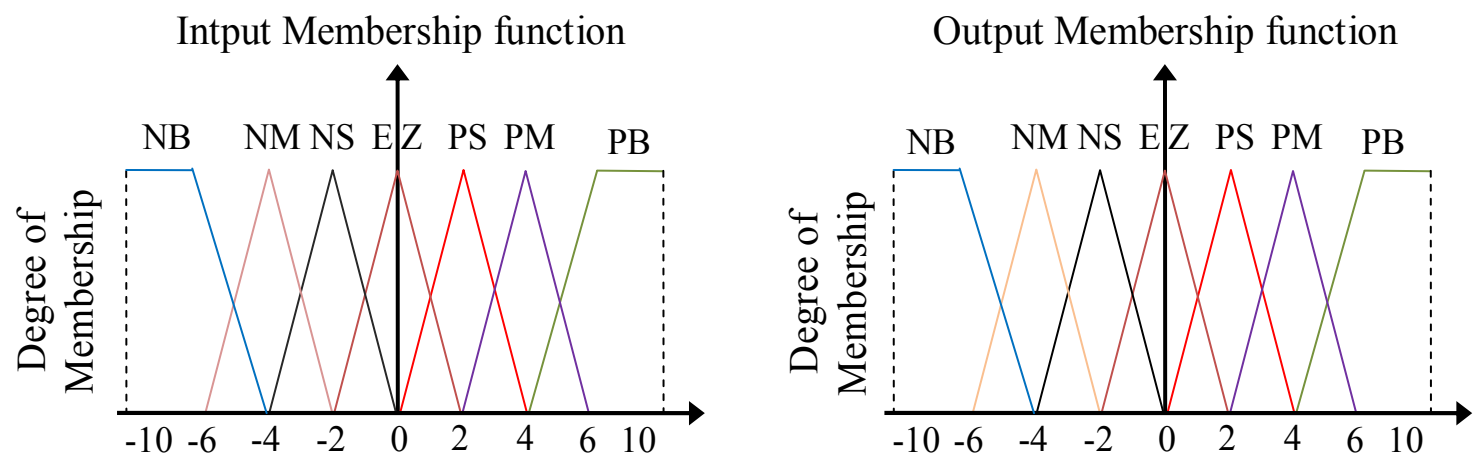

Fig. 5 Fuzzy sets and its memberships functions. 
Table 1 FL ruls of hysteresis comparators

\begin{tabular}{|c|c|c|c|c|c|c|c|}
\hline e1 & \multirow[t]{2}{*}{ NB } & \multirow[t]{2}{*}{$\mathbf{N M}$} & \multirow[t]{2}{*}{ NS } & \multirow[t]{2}{*}{ EZ } & \multirow[t]{2}{*}{ PS } & \multirow[t]{2}{*}{$\mathbf{P M}$} & \multirow[t]{2}{*}{ PB } \\
\hline$\Delta \mathrm{e} 1$ & & & & & & & \\
\hline NB & NB & NB & NB & NB & $\mathrm{NM}$ & NS & EZ \\
\hline $\mathbf{N M}$ & NB & $\mathrm{NB}$ & NB & NM & NS & EZ & $\overline{\mathrm{PS}}$ \\
\hline NS & NB & NB & $\mathrm{NM}$ & NS & EZ & PS & $\mathrm{PM}$ \\
\hline EZ & NB & $\mathrm{NM}$ & NS & EZ & PS & PM & PB \\
\hline PS & NM & $\mathrm{NS}$ & EZ & PS & $\mathrm{PM}$ & PB & PB \\
\hline PM & NS & EZ & PS & $\mathrm{PM}$ & PB & PB & PB \\
\hline PB & EZ & PS & PM & PB & PB & PB & PB \\
\hline
\end{tabular}

The Table 2 shows the parameters of fuzzy controller for the PWM inverter.

Table 2 Parameters of fuzzy controller

\begin{tabular}{|l|l|}
\hline Fis type & Mamdani \\
\hline And method & Min \\
\hline Or method & Max \\
\hline Implication & Min \\
\hline Aggregation & Max \\
\hline Defuzzification & Centroid \\
\hline
\end{tabular}

flux ripple, stator current ripple, and robustness against induction motor parameter variations.

The general structure of the IM with two-level PWM with fuzzy logic technique is represented by Fig. 6 .

Table 3 Implementation parameters

\begin{tabular}{|l|l|}
\hline Parameters & Values \\
\hline Nominal power & $1 \mathrm{MW}$ \\
\hline Line to line voltage & $791 \mathrm{~V}$ \\
\hline Frequency & $60 \mathrm{~Hz}$ \\
\hline Stator resistance & $0.228 \Omega$ \\
\hline Stator inductance & $0.0084 \mathrm{H}$ \\
\hline Rotor resistance & $0.332 \Omega$ \\
\hline Rotor inductance & $0.0082 \mathrm{H}$ \\
\hline Mutual inductance & $0.0078 \mathrm{H}$ \\
\hline Inertia & $20 \mathrm{Kg} . \mathrm{m}^{2}$ \\
\hline Friction & $0.008 \mathrm{~N} . \mathrm{m} . \mathrm{s}$ \\
\hline Number of poles & 3 \\
\hline
\end{tabular}

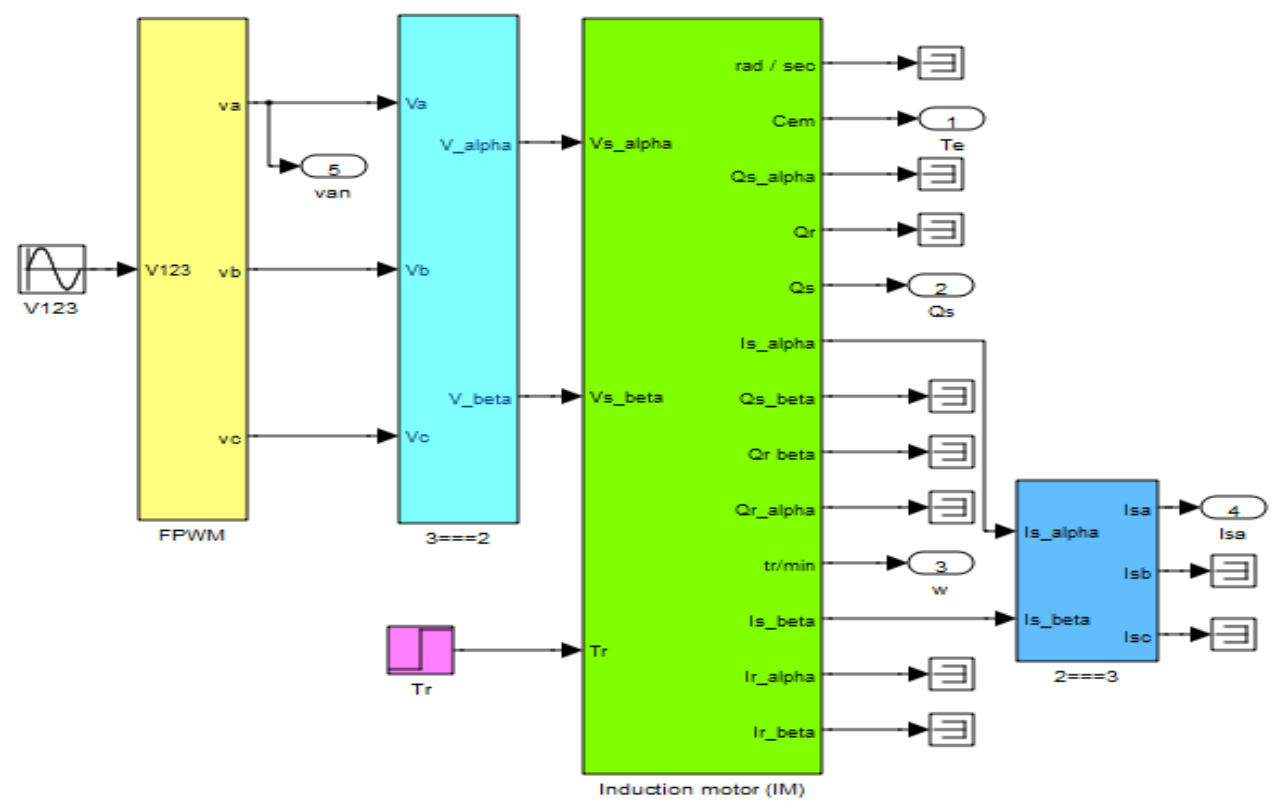

Fig. 6 IM drive with FPWM inverter.

\section{RESULTS}

Simulation of the proposed modulation strategies for an induction motor is conducted by using the Matlab/Simulink package. The induction motor is connected to a $791 \mathrm{~V} / 60 \mathrm{~Hz}$ grid. On the other hand, the induction motor is rated at $1 \mathrm{MW}$, and its parameters are listed in Table 3 . both modulation strategies traditional PWM technique and FPWM technique are simulated and compared in terms of reference tracking, stator current harmonics distortion, electromagnetic torque ripple, stator

\subsection{Reference Tracking Test (RTT)}

Figs. 7-13 show the obtained simulation results for tracking test of the IM. As it's shown by Figs. 12-13 show the harmonic spectrums of stator current and stator voltage of the IM obtained using Fast Fourier Transform (FFT) technique for both proposed modulation strategies. It can be clearly observed that the THD is more and more reduced for FPWM strategy. Table 4 shows the comparative analysis of the THD value of stator current and stator voltage for proposed modulation strategies. 
Table 4 Comparative analysis of THD value

\begin{tabular}{|l|c|c|}
\cline { 2 - 3 } \multicolumn{1}{c|}{} & \multicolumn{2}{c|}{ THD (\%) } \\
\cline { 2 - 3 } \multicolumn{1}{c|}{} & PWM & FPWM \\
\hline Stator current & 16.86 & $\mathbf{0 . 1 7}$ \\
\hline Stator voltage & 81.47 & $\mathbf{0 . 7 6}$ \\
\hline
\end{tabular}

Figs. 14-16 show the zoom in the electromagnetic torque, stator flux, and stator current of the traditional PWM and FPWM technique. This figure shows that the ripple of electromagnetic torque, stator flux, and stator current in the FPWM strategy has been zero compared with the traditional PWM strategy. It is clear from the results that the proposed FPWM technique has satisfied performance.

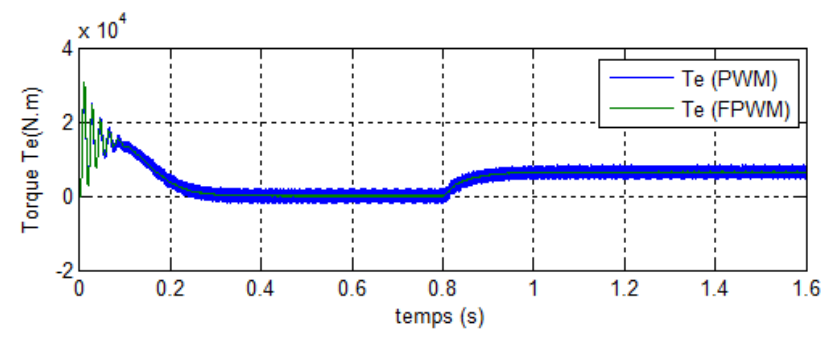

Fig. 7 Electromagnetic torque (RTT)

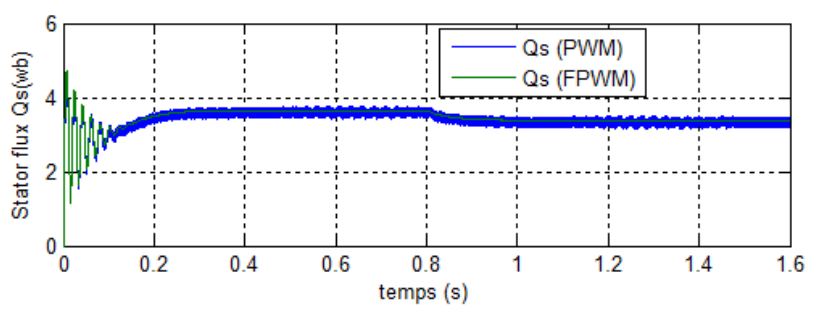

Fig. 8 Stator flux (RTT)

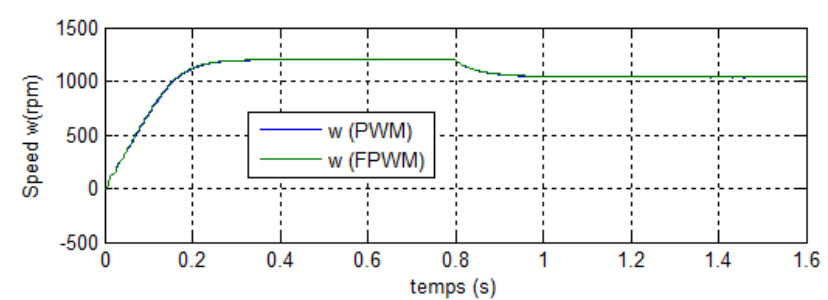

Fig. 9 Speed (RTT)

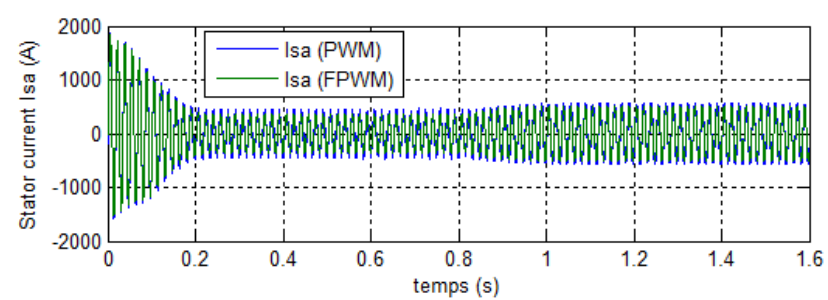

Fig. 10 Stator current (RTT)

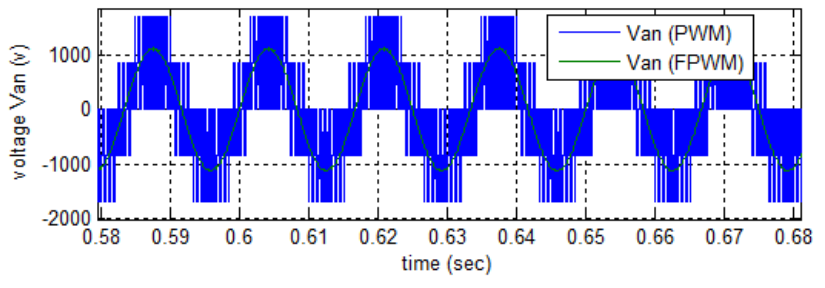

Fig. 11 Stator voltage (RTT)
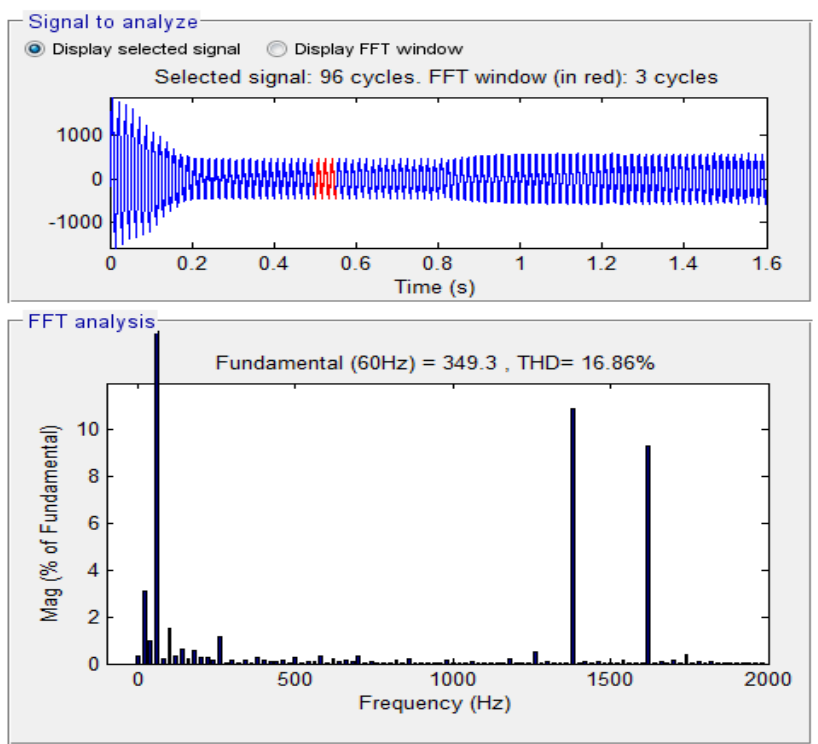

a)PWM
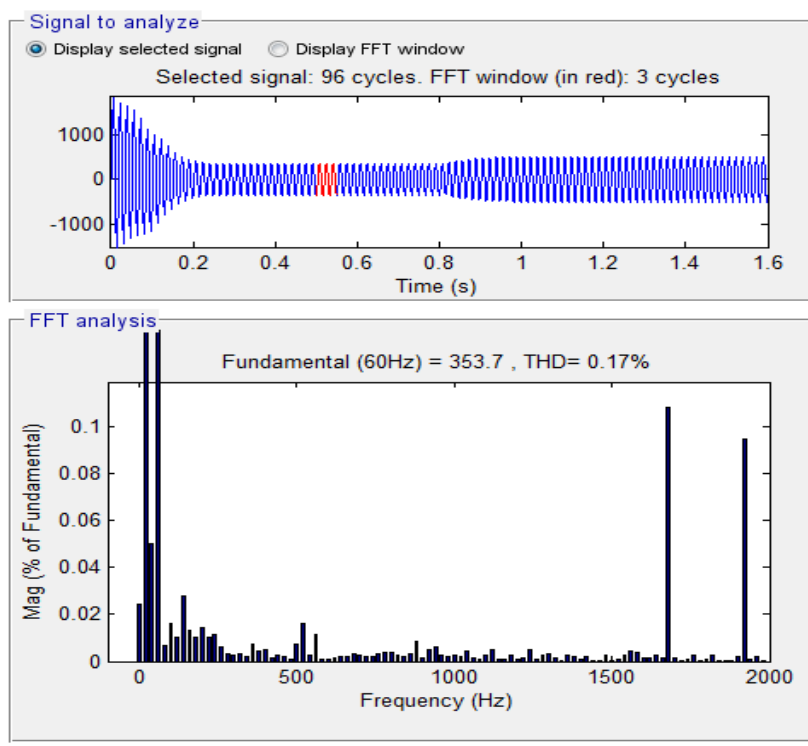

b)FPWM

Fig. 12 THD of one phase stator current for the IM drive (RTT). 


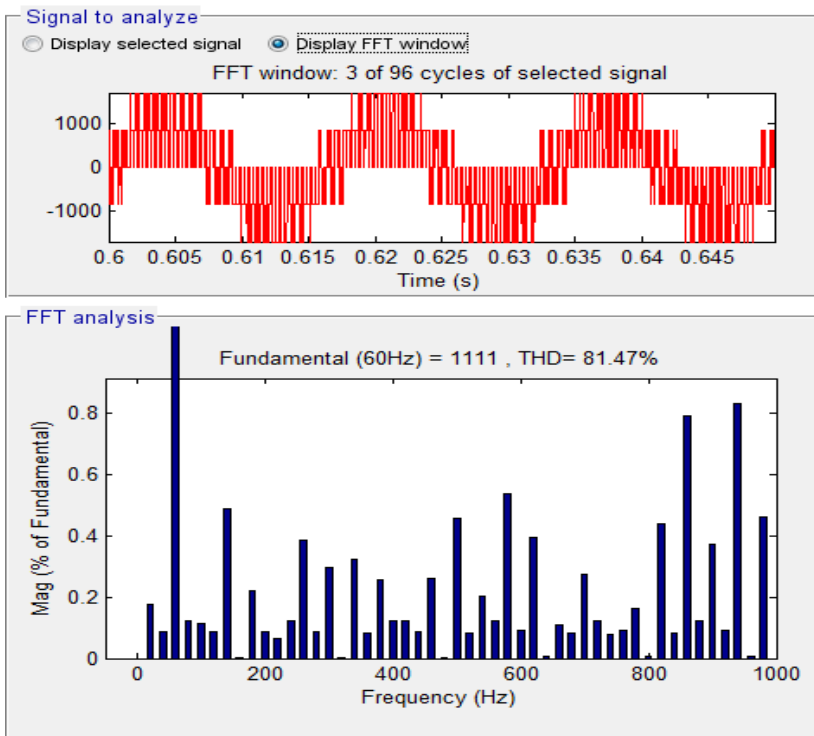

a) PWM

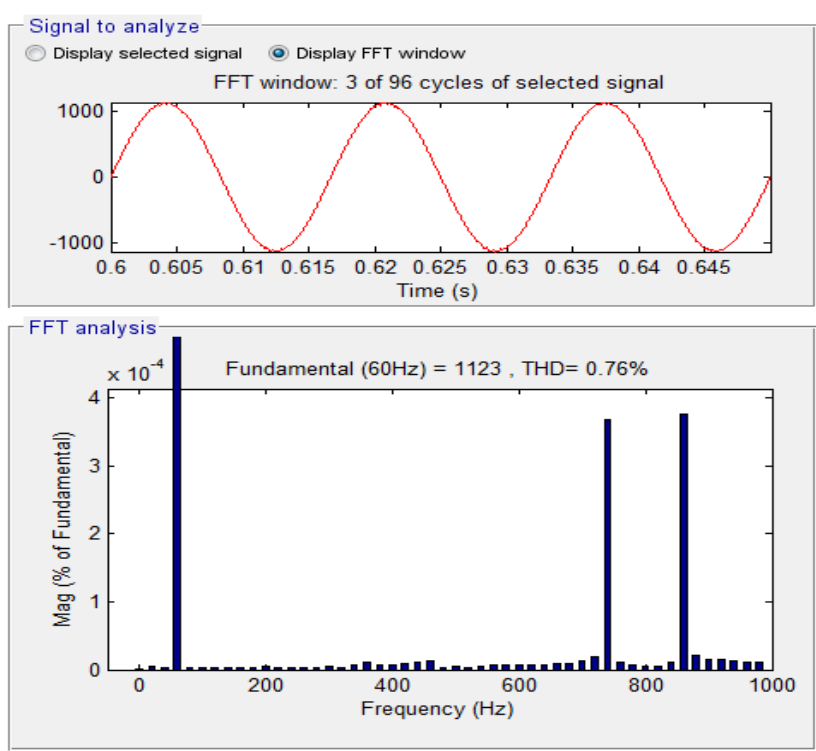

b)FPWM

Fig. 13 THD of one phase stator voltage for the IM drive (RTT).

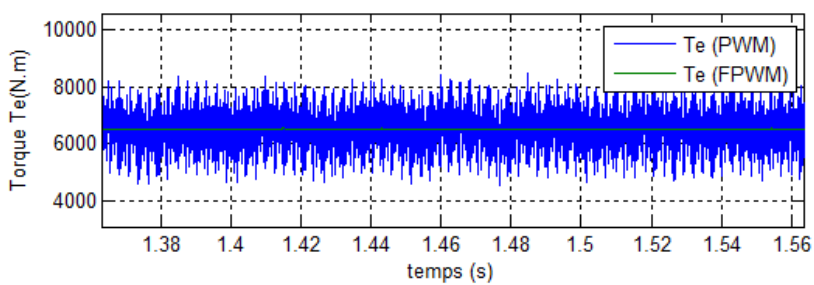

Fig. 14 Zoom in the electromagnetic torque (RTT)

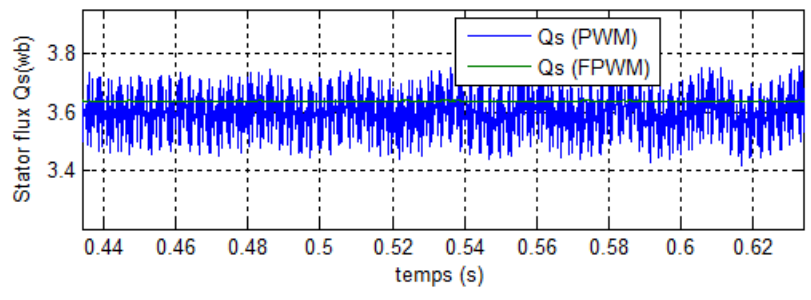

Fig. 15 Zoom in the stator flux (RTT)

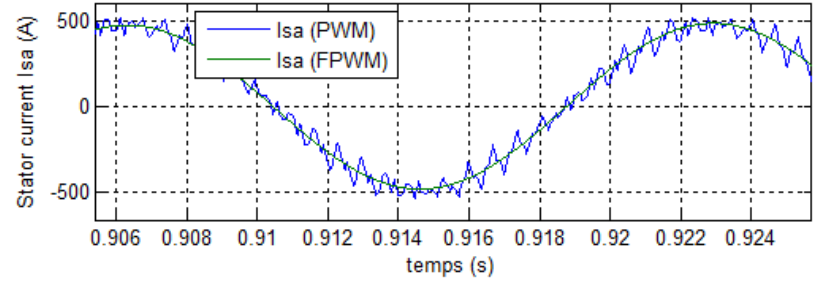

Fig. 16 Zoom in the stator current (RTT).

\subsection{Robustness Test (RT)}

In order to examine the robustness of the proposed modulation strategies of the IM drive, the nominal value of the $R_{r}$ and $R_{s}$ is multiplied by 2 , the values of inductances $L_{s}, \mathrm{M}$, and $\mathrm{L}_{\mathrm{r}}$ are multiplied by 0.5 . Simulation results are presented in Figs 17-23. As it's shown by these Figures, these variations present a clear effect on the electromagnetic torque, stator current, and stator flux curves and that the effect appears more and more important for the traditional PWM strategy. On the other hand, these results show that the THD value of stator voltage and stator current in the FPWM strategy has been reduced significantly. Table 5 shows the comparative analysis of THD value.

Figs. 23-25 show the zoom in the electromagnetic torque, stator flux, and stator current of the traditional PWM strategy and FPWM strategy. This figure shows that the ripple of electromagnetic torque, stator flux, and stator current in the FPWM strategy has been zero compared with the traditional PWM technique. Thus it can be concluded that the proposed FPWM technique is more and more robust than the traditional PWM one.

Table 5 Comparative analysis of THD value (RT)

\begin{tabular}{|l|c|c|}
\cline { 2 - 3 } \multicolumn{1}{c|}{} & \multicolumn{2}{c|}{ THD (\%) } \\
\cline { 2 - 3 } \multicolumn{1}{c|}{} & PWM & FPWM \\
\hline Stator current & 17.17 & $\mathbf{0 . 1 7}$ \\
\hline Stator voltage & 81.47 & $\mathbf{0 . 7 6}$ \\
\hline
\end{tabular}

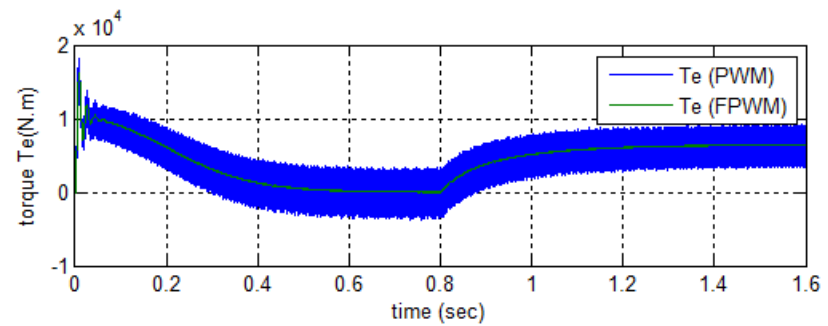

Fig. 17 Electromagnetic torque (RT)

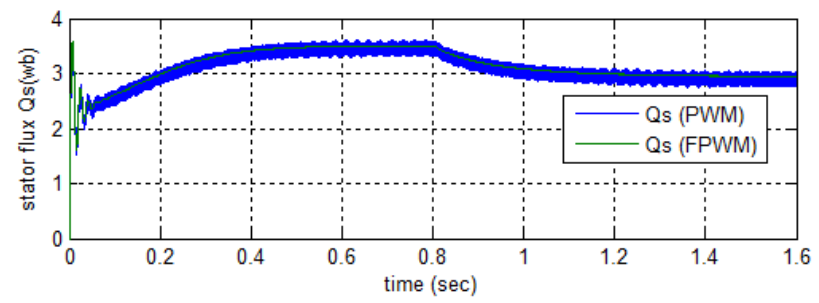

Fig. 18 Stator flux (RT) 


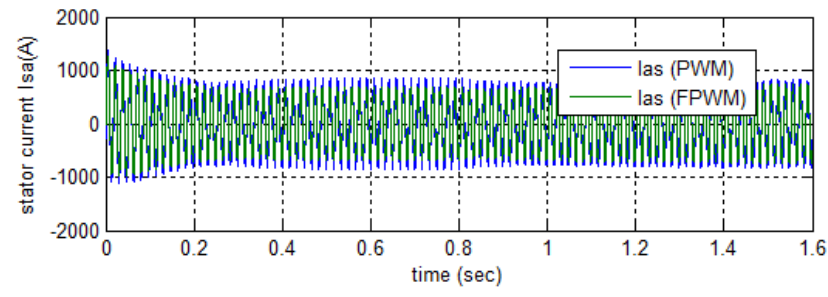

Fig. 19 Stator current (RT).

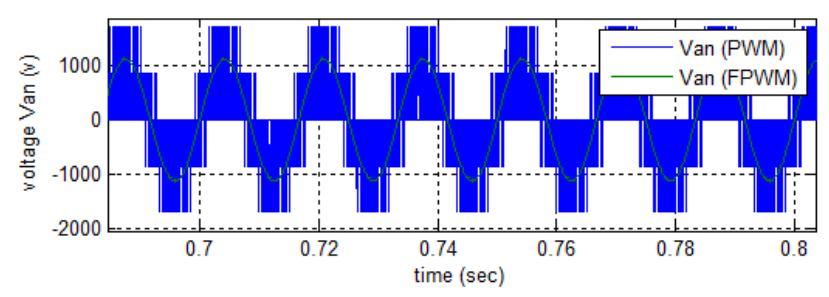

Fig. 20 Stator voltage (RT).
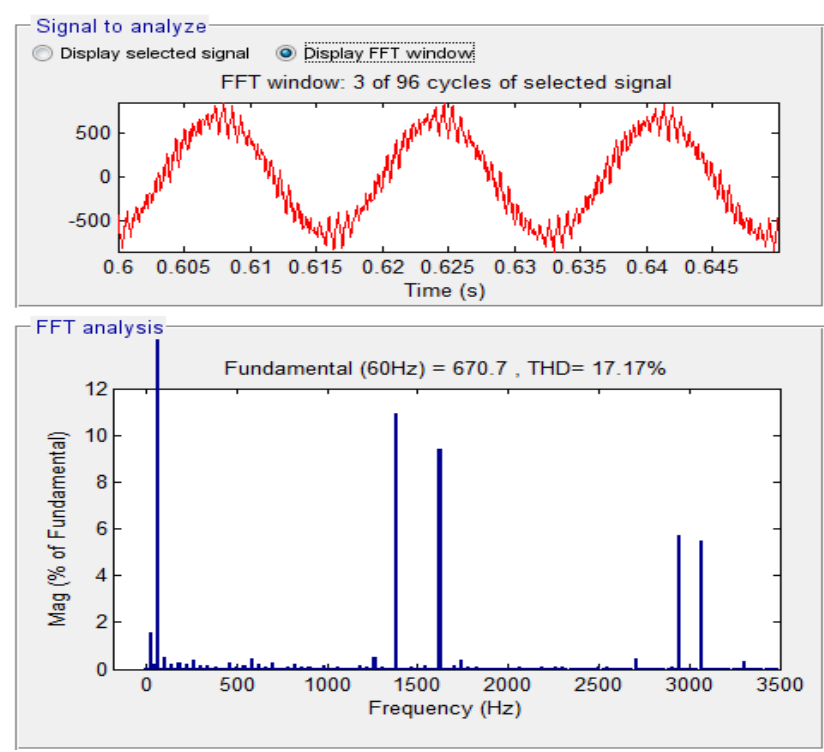

a)PWM
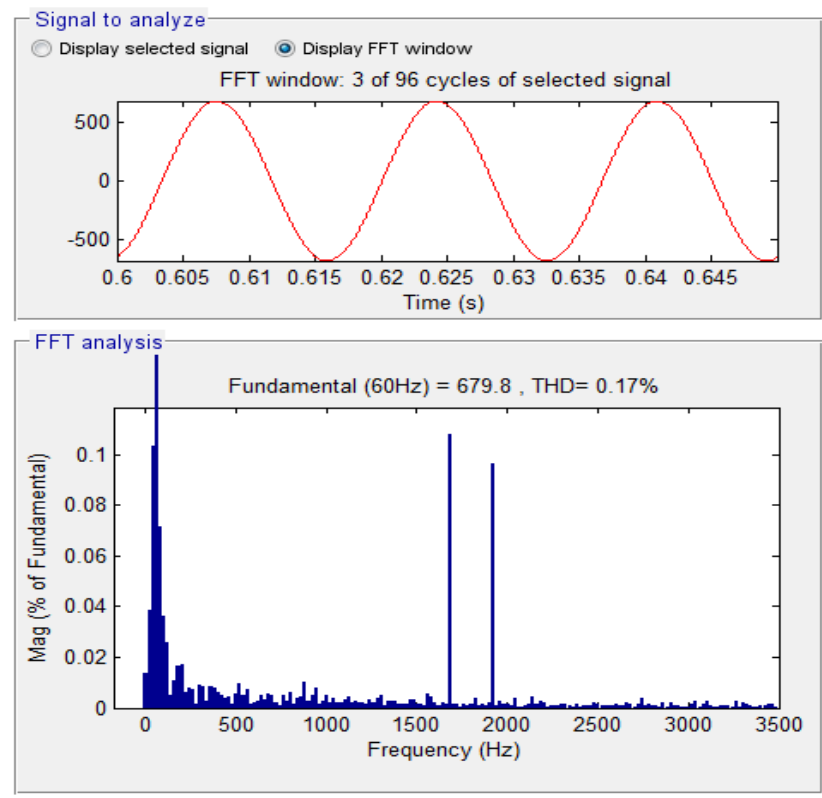

b)FPWM

Fig. 21 THD of one phase stator current for the IM drive (RT).

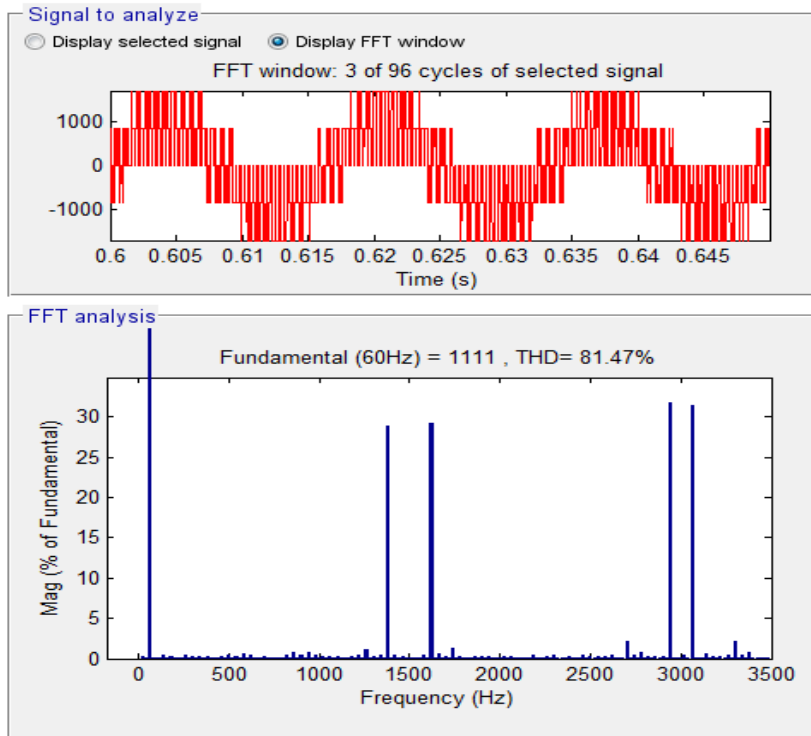

a)PWM
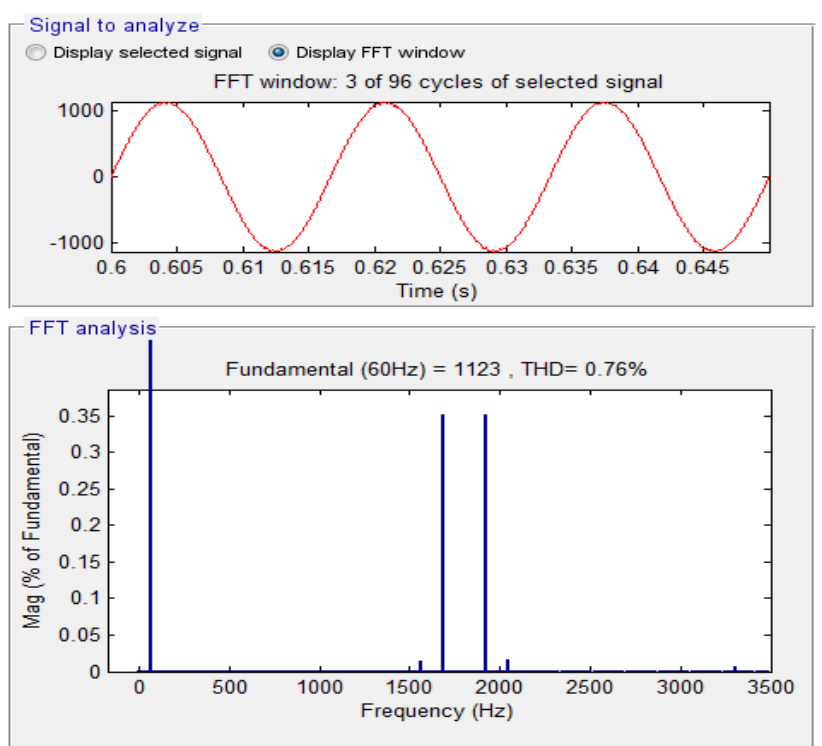

b)FPWM

Fig. 22 THD of one phase stator voltage for the IM drive (RT).

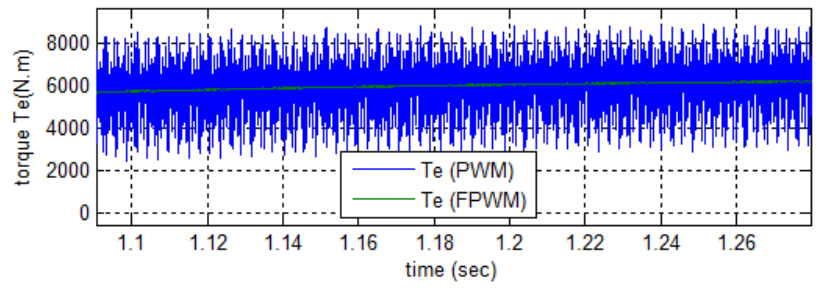

Fig. 23 Zoom in the Electromagnetic torque (RT)

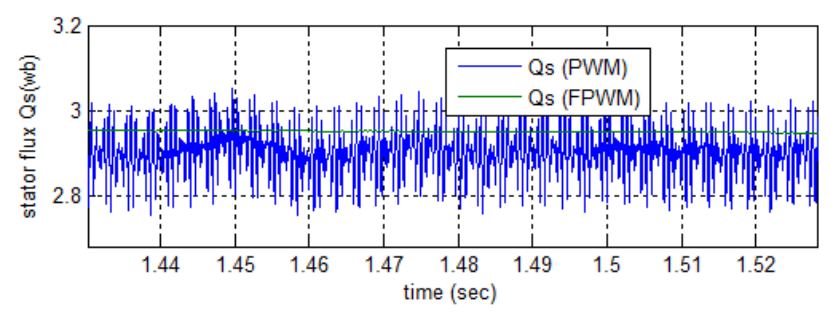

Fig. 24 Zoom in the stator flux (RT). 


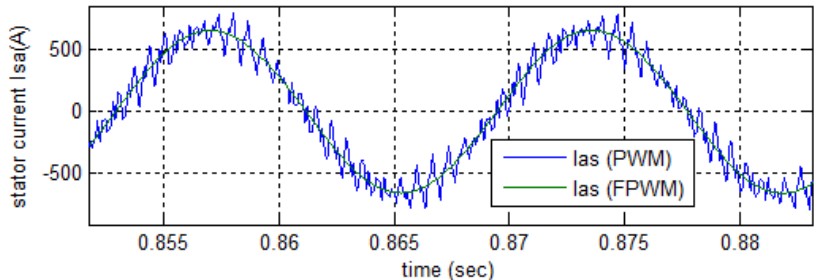

Fig. 25 Zoom in the stator current (RT).

\subsection{Changes in Load Torque (CLT)}

In this section, it is apparent that the stator flux ripple, stator current and torque ripple for the tow-level FPWM inverter is considerably reduced (See Figs. 26-29 and Figs. 32-34).

Figs. 30-31 show the harmonic spectrums of stator current and stator voltage of the IM using PWM and FPWM inverter. It can be clearly observed that the THD is more reduced for FPWM strategy. Table 6 shows the comparative analysis of the THD value of stator current and stator voltage for proposed modulation strategies.

Table 6 Comparative analysis of THD value (CLT)

\begin{tabular}{|l|c|c|}
\cline { 2 - 3 } \multicolumn{1}{c|}{} & \multicolumn{2}{c|}{ THD (\%) } \\
\cline { 2 - 3 } \multicolumn{1}{c|}{} & PWM & FPWM \\
\hline Stator current & 11.57 & $\mathbf{0 . 1 2}$ \\
\hline Stator voltage & 81.40 & $\mathbf{0 . 7 6}$ \\
\hline
\end{tabular}

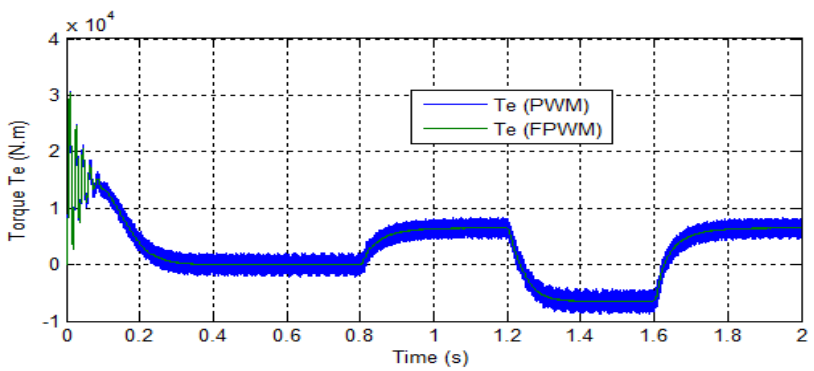

Fig. 26 Electromagnetic torque (CLT).

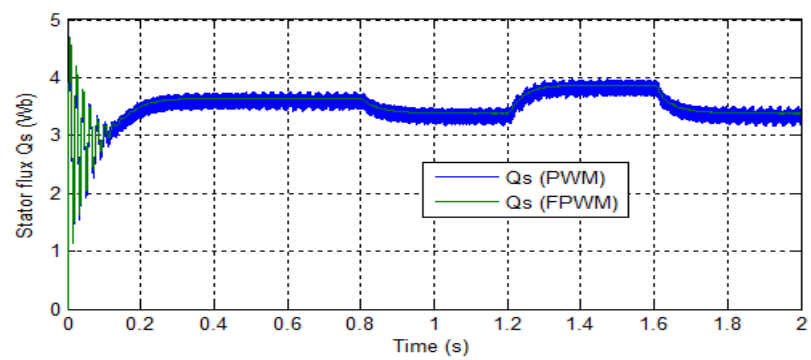

Fig. 27 Stator flux (CLT).

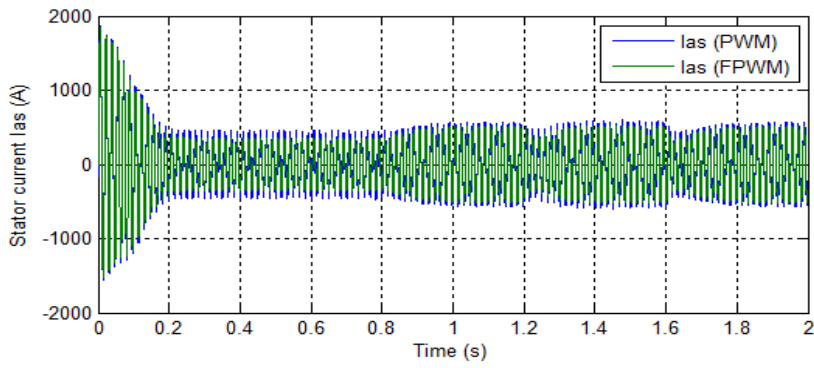

Fig. 28 Stator current (CLT).

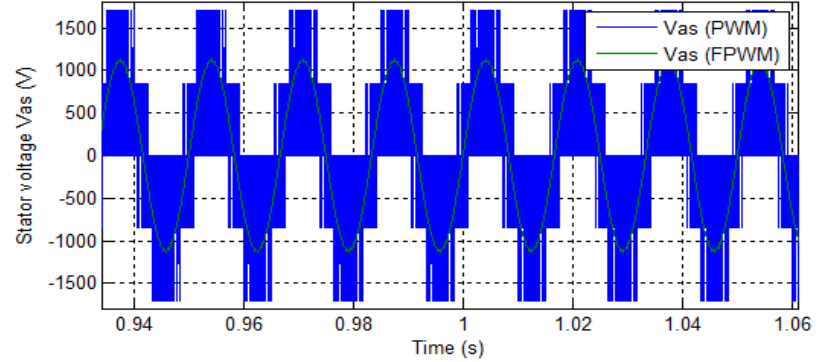

Fig. 29 Stator voltage (CLT).
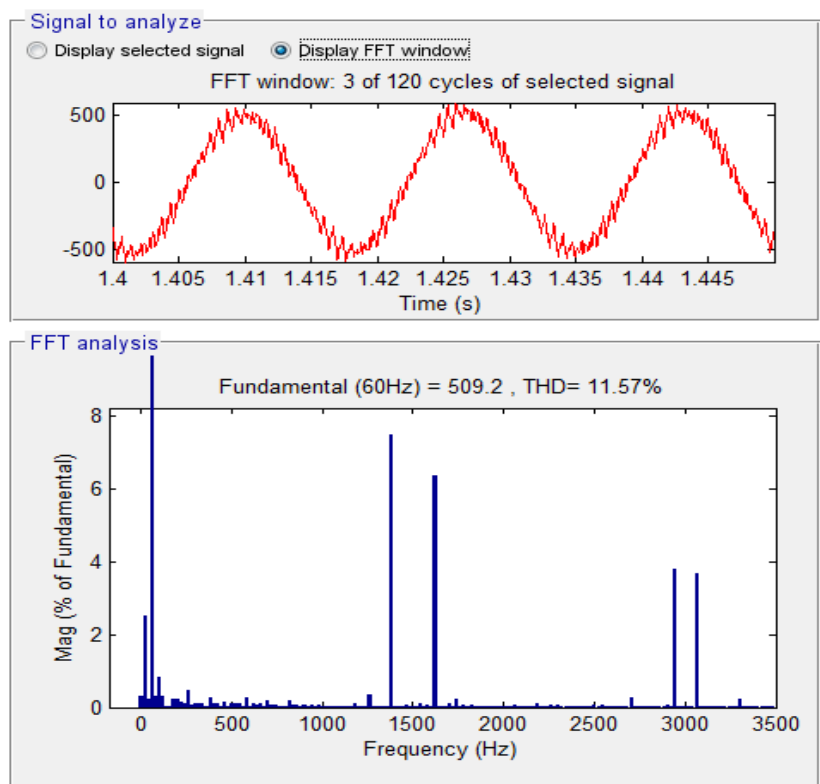

a)PWM
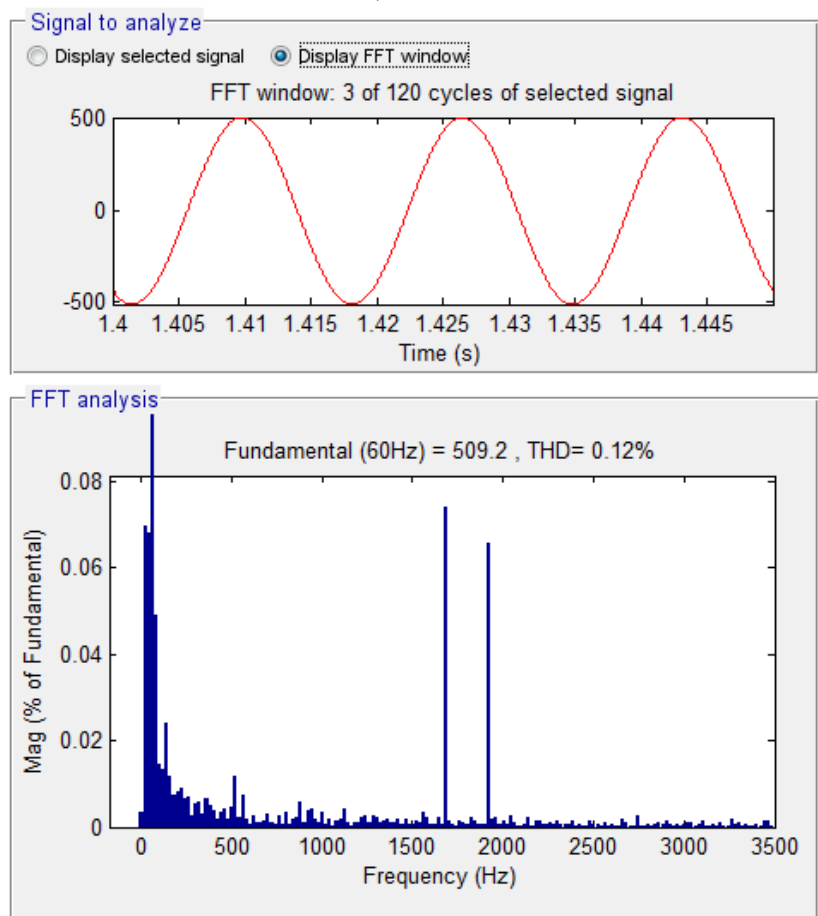

b)FPWM

Fig. 30 THD of one phase stator current for the IM drive (CLT). 

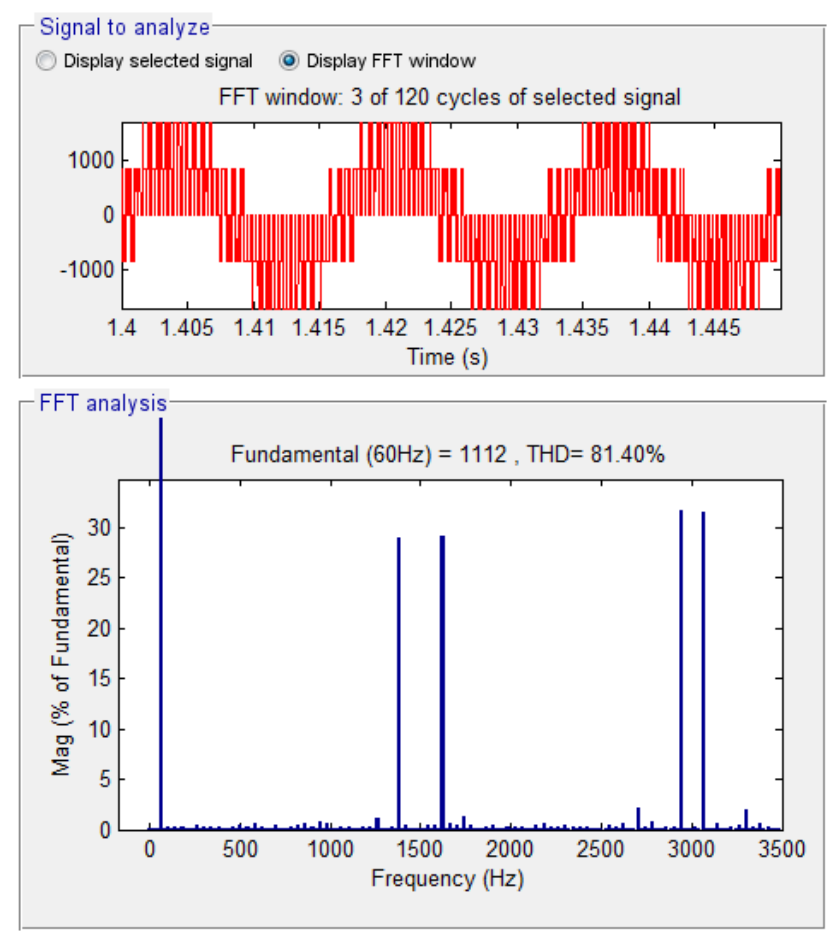

a)PWM
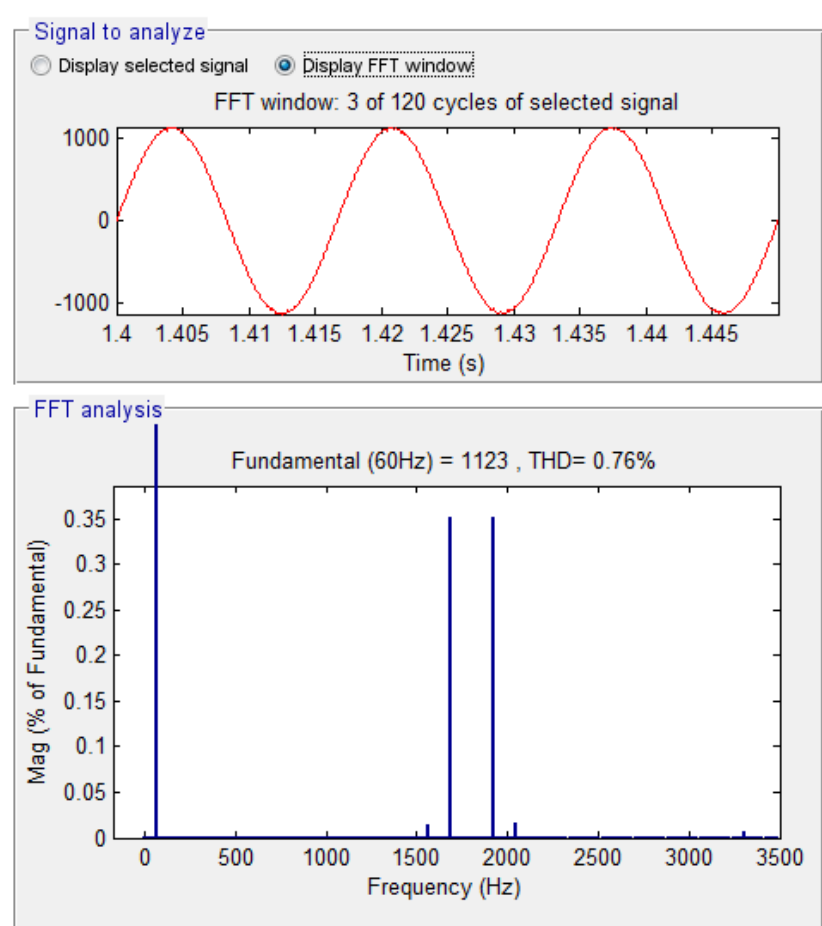

b)FPWM

Fig. 31 THD of one phase stator voltage for the IM drive (CLT).

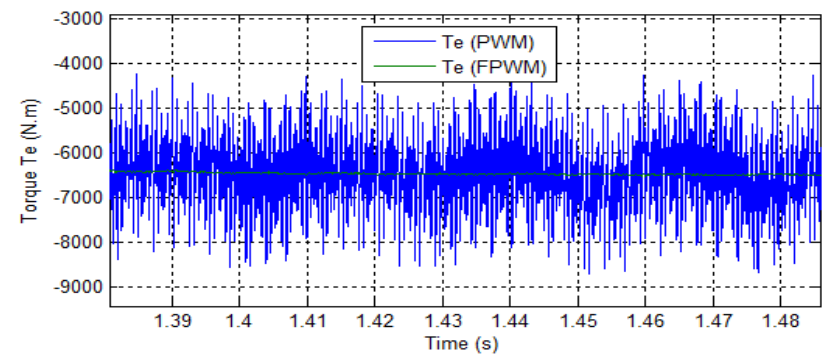

Fig. 32 Zoom in the electromagnetic torque (CLT).

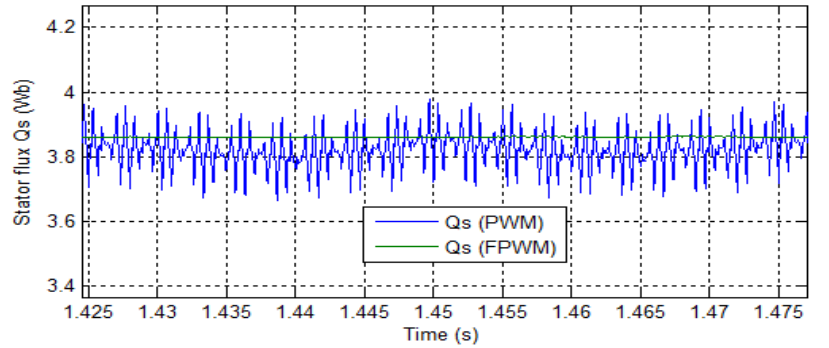

Fig. 33 Zoom in the stator flux (CLT).

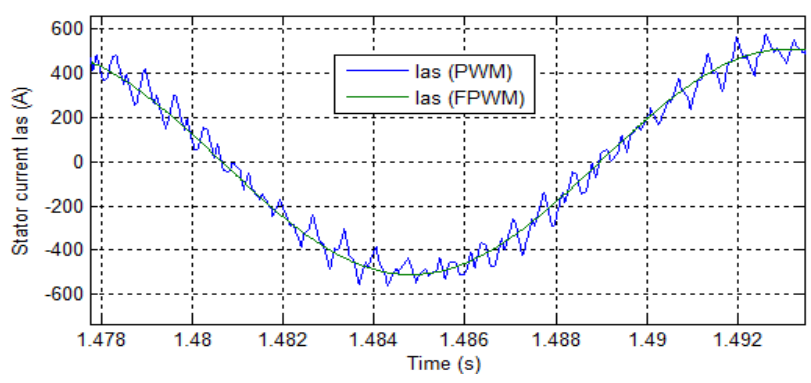

Fig. 34 Zoom in the stator current (CLT).

\section{CONCLUSIONS}

The paper presents the simulation of a new pluse width modulation scheme based on fuzzy logic for induction motor. The comparaison through simulations between conventional PWM technique and FPWM strategy have been done. The simulation result has shown that the reduction of stator flux ripple, electromagnetic torque ripple and THD value of stator current and stator voltage can be achieved through the FPWM technique. The simulation results obtained were satisfactory, and system solidity has been insured.

\section{REFERENCES}

[1] IDIR, A. - KIDOUCHE, M.: Direct torque control of three phase induction motor drive using fuzzy logic controllers for low torque ripple, Proceedings Engineering \& Technology, Vol. 2, pp. 78-83, 2013.

[2] BERREZZEK, F. - BOURBIA, W. - BENSAKER, B.: Flatness based nonlinear sensorless control of induction motor systems, International Journal of Power Electronics and Drive System, Vol. 7, No. 1, pp. 265-278, 2016.

[3] RAJASEKARAN, P. - SENTHILKUMAR, V. J.: An improved DTFC based five levels-NPC inverter fed induction motor for torque ripple minimization, International Journal of Power Electronics and Drive System, Vol. 7, No. 2, pp. 531-542, 2016.

[4] MASSOUM, S. - MEROUFEL, A. - MASSOUM, A. - WIRA, P.: A direct power control of the doubly-fed induction generator based on the SVM strategy, Elektrotehniski Vestnik, Vol. 45, No. 5, pp. 235-240, 2017.

[5] GABALLAH, M. - EL-BARDINI, M.: Low cost digital signal generation for driving space vector PWM inverter, Ain Shams Engineering Journal, Vol. 4, pp. 763-774, 2013. 
[6] KAVOUSI, A. - VAHIDI, B. - SALEHI, R. BAKHSHIZADAH, M. K. - FOROKHNIA, N. FATHI, S. H.: Application of the bee algorithm for selective harmonic elimination strategy in multilevel inverter, IEEE Transactions on Power Electronics, Vol. 27, No. 4, pp. 1689-1696, 2012.

[7] CHABNI, F. - TALEB, R. - HELAIMI, M.: Differential evolution based SHEPWM for sevenlevel inverter with non-equal DC source, International Journal of Advanced Computer Science and Applications, Vol. 7, No. 9, pp. 304-311, 2016.

[8] AGHION, C. - URSARU, O.: Three-phase inverter controlled by ISCPWM and DPWM-S1, Electronics and Electrical Engineering, Vol. 3, pp. 87-90, 2012.

[9] IBRAHIM, Z. B. - HOSSAIN, MD. L. - BUGIS, I. B. - MAHADI, N. M. N. - ABU HASIM, A. S.: Simulation investigation of SPWM, THIPWM and SVPWM techniques for three phase voltage source inverter, International Journal of Power Electronics and Drive System, Vol. 4, No. 2, pp. 223-232, 2014.

[10] CHATURVEDI, L. - YADAV, D. K. - PANCHOLI, G.: Comparison of SPWM, THIPWM and PDPWM techniques based voltage source inverters for application in renewable energy, Journal of Green Engineering, Vol. 7, pp. 83-98, 2017.

[11] LYU, J. - HU, W. - WU, F. - YAO, K. - WU, J.: A new DPWM method to suppress the low frequency oscillation of the neutral-point voltage for NPC threelevel inverters, Journal of Power Electronics, Vol. 15, No. 5, pp.1207-1216, 2015.

[12] BEKAKRA, Y. - BEN ATTOUS, D.: Comparison study between SVM and PWM inverter in sliding mode control of active and reactive power control of a DFIG for variable speed wind energy, International Journal of Renable Energy Research, Vol. 2, No. 3, pp. 471-476, 2012.

[13] BOUDJEMA, Z. - MEROUFEL, A. - DJERIRI, Y. - BOUNADJA, E.: Fuzzy sliding mode control of a doubly fed induction generator for wind energy conversion, Carpathian Journal of Electronic and Computer Engineering, Vol. 6, No. 2, pp. 7-14, 2013.

[14] ŻELECHOWSKI, M. : Space vector modulateddirect torque controlled (DTC-SVM) inverter-fed induction motor drive, Ph.D. Thesis, Warsaw University of Technology, 2005.
[15] TALEB, R. - BENYOUCEF, D. - HELAIMI, M. BOUDJEMA, Z. - SAIDI, M.: Cascaded H-bridge asymmetrical seven-level inverter using THIPWM for high power induction motor, Energy Procedia, Vol. 74, pp. 844-853, 2015.

[16] YAHDOU, A. - HEMICI, B. - BOUDJEMA, Z.: Second order sliding mode control of a dual-rotor wind turbine system by employing a matrix converter, Journal of Electrical Engineering, Vol. 16, No.4, pp. 1-11, 2016.

[17] PALANIVELU, M. - DURAISANY, M.: Color textured image segmentation using ICICM-intervel type-2 fuzzy C-means clustering hybrid approach, Engineering Journal, Vol. 16, No. 5, pp. 115-126, 2012.

[18] HENDEL, R. - KHABER, F. - ESSOUNBOULI, N.: Adaptive type-2 fuzzy second order sliding mode control for nonlinear uncertain chaotic system, International Journal of Computational Science, Information Technology and Control Engineering, Vol. 2, No. 4, pp. 1-14, 2015.

[19] BENBOUHENNI, H. - BOUDJEMA, Z.: Speed regulator and hysteresis based on artificial intelligence techniques of three-level DTC for induction motor, Acta Electrotechnica et Informatica, Vol. 17, No. 4, pp. 50-56, 2017.

[20] BAKOURI, A. - MAHMOUDI, H. - ABBOU, A.: Intelligent control for doubly fed induction generator connected to the electrical network, International Journal of Power Electronics and Drive System, Vol. 7, No. 3, pp. 688-700, 2016.

Received April 04, 2018, accepted January 11, 2019

\section{BIOGRAPHY}

Habib Benbouhenni was born in chlef, Algeria. He is a $\mathrm{PhD}$ student in the Departement of electrical engineering at the ENPO-MA, Oran, Algeria. He received a M.S. degree in Automatic and informatics industrial in 2017. His research activities include the application of robust command in the wind turbine power systems. 